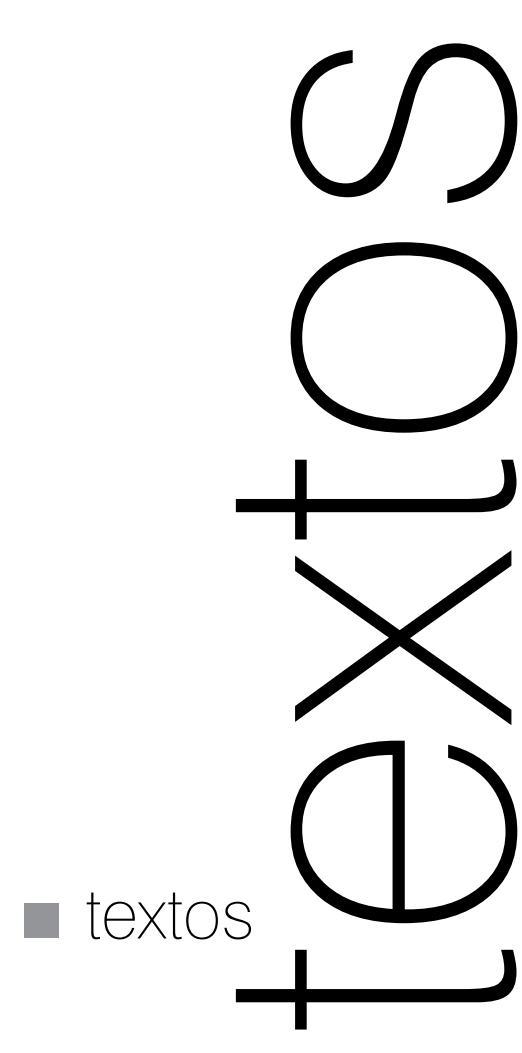




\section{Marilyn Contardi}

\section{Impresión a partir de una foto. William Faulkner, por H.C.-Bresson}

De modo que éste es. William Faulkner. Él es. El hombre que imaginó, escribió, Mientras yo agonizo, $A b$ salon, Absalon, Luz de Agosto... El que abrió puertas para dar paso al coronel Sartoris, a Anse, Dash, Dewy-Dell, la señorita Emily, Popeye, Caddy... ¿Desde cuándo estuvieron con él esos seres?, ¿cómo fue que sus voces empezaron a hacerse oír?, y ¿cuándo fue que él empezó a tomarlas en cuenta?

¿...las dejó venir, las dejó asentarse en él...o esas voces eran él? ¿De dónde venían? ¿De qué recodos del campo? ¿Cuáles campos? ¿De zonas tan íntimas y tan antiguas que se habían fundido con su misma naturaleza? ¿Era el campo que había visto cuando niño o del que había oído hablar a los mayores cuando era muy niño y ya no sabía si el mismo lo había conocido o si sólo lo conocía a través de los dichos de los mayores? Tal vez había visto los últimos habitantes de esos recodos, de esos villorios, llegar a la plaza, a los almacenes, adónde él había ido llevado en brazos o de la mano por los grandes, y mientras estaban sentados ahí, en los bancos o acuclillados en un rincón mientras, lo tenían entre sus rodillas y el los escuchaba; oía como los que llegaban entraban arrastrando los pies, envueltos en incomodidad, arrastrando también los palabras al hablar como si desconfiaran de las palabras mismas que les iban saliendo, y a él le llegaban como en un sueño entre el humo de las pipas y de los cigarros...

Había estado quizá largamente susurrando en su oído ese Anse, o aquella Dilsey... Pero... ¿y a quién se parecían?, ¿o le recordaban a quién?... ¿y la señora Compson, y Quentin y Lucas...?

Pero él era muy chico para darse cuenta y solo vivía para su edad, hasta que en un momento los empezó a oír, incluso contra su voluntad, y supo que era Anse 
el que le decía: “... Hago lo que puedo. Ante Dios digo que no hay nadie en este mundo que haya pasado por las humillaciones y penas que yo he pasado... Llevo quince años sin un diente en la boca. Dios lo sabe. Sabe que durante quince años no he podido comer los alimentos...", y después de quejarse de ese modo, se había puesto en sus brazos, se había hecho llevar por él, hasta que pudo encontrarle (un lugar en uno de sus libros.

¿Qué de todo aquello zumba aún en él, ahora, en medio de la luz? ¿Qué pensamientos son los que corren por su mente mientras está allí, en medio de ese aire, "sobre su superficie impalpable súbita y soñada" en medio de la calma de una ensoñación de luz y sombra; es una ensoñación o él esta atento a otra cosa? Abstraído y atento a la vez, y se deja estar ahí con la naturalidad de una planta, un pájaro o cualquiera de esos ratoneros atentos y desenfadados que lo acompañan. Atención a algo que puede parecer a algunos cosa menor, pero que indudablemente no lo es: un ratonero es un perro con clase, estén donde estén, en el norte del continente o en el sur, porque aún $-y$ el aún vale para el momento en que están con él, su dueño, en el patio - no han sido adulterados sus genes por el cruce de razas como tal vez sucederá después y todos, también los que frecuentaron nuestros patios y galpones en los pueblos de provincia, poseyeron esa nobleza perruna que les venía de la estirpe de sus ancestros los terriers ingleses.

No hay manera de saber con qué intensidad la vida está fluyendo en él, William Faulkner, en este momento, no hay manera de espiar esas corrientes que lo atraviesan...

De modo que... él esta ahí, entre el sol y la sombra filtrada por los árboles. Mirando hacia un costado de la

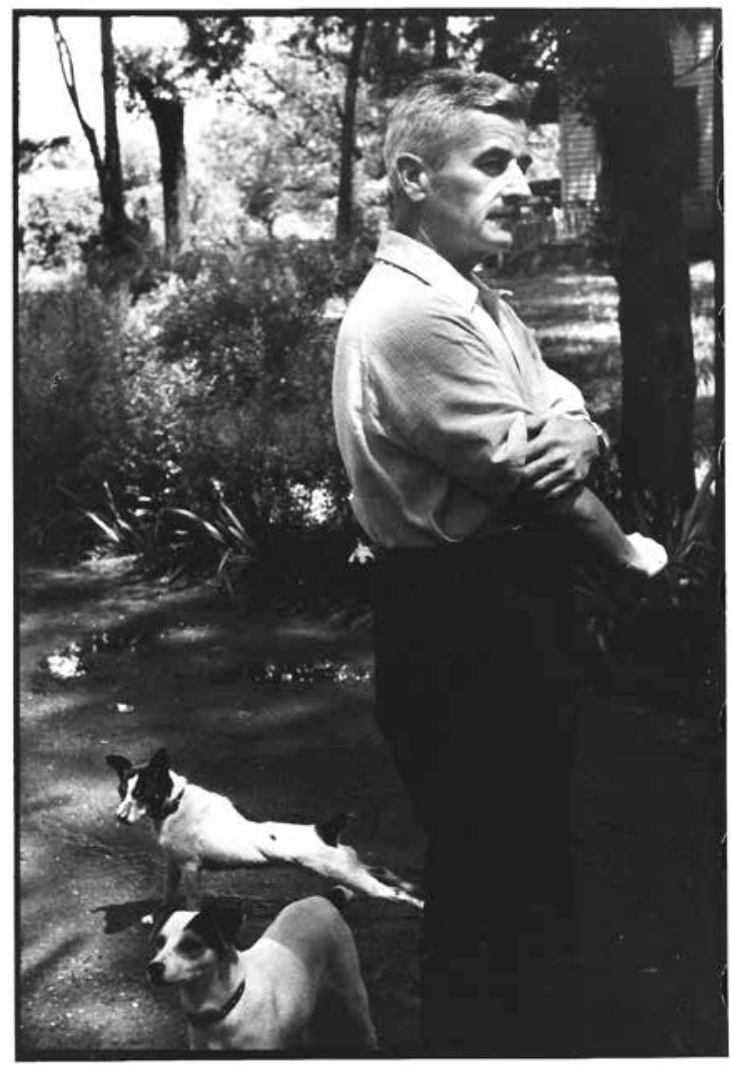


casa, del espacio que rodea la casa y sabe que lo están mirando. Algunos pasos detrás de él, el hombre con su cámara lo esta mirando, lo esta enfocando, porque el ojo de la cámara es el ojo del hombre, un hombre alto, diligente, implacablemente silencioso y consecuente con su cámara, y que él, William Faulkner, está en, es el centro de esa mirada, que literal y figuradamente en ese momento es "la niña de los ojos" del fotógrafo.

El cuerpo delgado, nervioso, está disponible y a la vez se recoge sobre sí mismo reteniendo uno de los brazos contra su costado.

El perrito está a sus pies, complacido, encantado de estar ahí a su lado, sintiendo también él, todavía más él, porque por su instinto está más alerta, la presencia del hombre con la cámara, que si bien es una presencia extraña en el lugar, no es una presencia hostil. No, no ha emitido ondas agresivas, no le han llegado a él señales de peligro inminente, desde ese ser que sobrepasa varias pulgadas en altura a su dueño. Simplemente, ha observado que el hombre con la cámara viene siguiendo a su amo desde hace un buen rato, con ese pequeño adminículo que cabe entero en su mano a la altura del ojo; lo ha visto caminar mirando a través de ese adminículo, y él, perrito fiel, devoto de su amo, ha sentido, a su modo, algo que por carecer de nombre, diremos que es algo parecido al orgullo de los humanos, por pertenecer a su cír- culo. El otro ratonero, su compañero, está allí cerca, pero no parece haber advertido lo que él advierte; o no con la misma intensidad, como sea, tal vez esta atento a otra cosa que él, por estar más atento a su amo y al hombre con la cámara que lo sigue, no ha percibido con la misma atención.

Y en un momento su dueño se detiene, y el extranjero, el hombre con la cámara se detiene junto a él, los dos sin estar tensos, están atentos el uno al otro, su dueño, sin hacerlo evidente, el otro, el fotógrafo manifestándose abiertamente y entonces él, el perrito, se estira, complacido a los pies de su amo, y es en ese momento, y el perrito lo siente, probablemente lo oye y lo siente al mismo tiempo, que el hombre con la cámara, hace presión con su dedo sobre el obturador y la incomparable Leica pone en marcha sus dispositivos, el delicado, luciente abanico de láminas de acero se abre y se cierra velocísimo en el interior, y en un instante, fugaz como un destello, "la presencia" de ese señor de cabello y bigotes canosos, sureño y cordial, su amo, William Faulkner, queda fijado, ahora inmaterial, o dicho de otro modo, su "reflejo vivo" junto al de él, el perrito, sí, en un instante de milagro casi, un instante parecido en su alucinación al del que va a nacer, cuya cabeza toma el partero entre sus manos, y saca de un tirón al vasto mundo. Todo esto está en la foto que vemos ahora. Pero no está escrito en ningún libro. 